\title{
FISHERY SOCIO ECONOMICS OF VALAICHCHENAI LAGOON, SRI LANKA
}

\author{
Naganathan Z. and Wickramaratne I.U.* \\ Department of Animal Science, Uva Wellassa University, Badulla, Sri Lanka \\ *Corresponding Author: indikau@uwu.ac.lk (https://orcid.org/0000-0001-6886-2852) \\ Received: 01.08.2021; Accepted: 25.09.2021; Published: 05.11.2021
}

\begin{abstract}
Valaichchenai lagoon is one of the major inland fishery sources in Batticaloa. However, status of fishery \& socio-economic information were lacking in literature, and this study aimed to fulfil this research gap. Primary data including fishing practices, species, marketing system and supply chain, catch per unit effort, sustainable fishery constraints, and environmental impacts of fishing \& related activities, were collected using questionnaire, interviews, and direct field observations. Secondary data were obtained from Fisheries Department of Batticaloa and journal articles. Total of 12 types of fishing gears and the outrigger lagoon canoes (Thoni) were used for fishing and 38 species were identified during study period. Only a very small percentage directly sells fish catch to final consumers, and supply chain includes local and foreign market interventions. Fishermen caught 0.009 to $0.027 \mathrm{~kg} / \mathrm{net}$ square meter-day, and 0.75 to $3.1 \mathrm{~kg} / \mathrm{day}$ using a gill net and cast net respectively, on average. Regulations for mesh sizes and certain unauthorized activities, licensing system, and seabass cage culture for sustainable fisheries have been imposed in Valaichchenai lagoon, but there were no species/size limitations, off-season/time limitations with prevailing irresponsible fishing (IUU), seagrass/benthic environment destruction, shrimp farm effluent discharge, disposal from cage fishing harbour $\&$ adjacent bout repairing centres, oil spilling from boats and sound pollution issues. It can be suggested that introducing a co-management system, implementing voluntary code of conduct, proper rules and regulations, frequent monitoring, conducting awareness programmes \& training programmes for the sustainability of Valachchenai lagoon fishery.
\end{abstract}

Keywords: Catch unit effort, Co-management, Fishery sustainability, Supply chain, Valaichchenai lagoon

\section{INTRODUCTION}

Valaichchenai Lagoon is situated between 81.548952-7.941750 and 81.554221-7.942600 in the vicinity of Passikudah Bay. It is an estuarine lagoon, encompassing an area of about $13.21 \mathrm{ha}$ which may provide nursery ground for many marine species. Its fisheries provide a primary source of income for at least 3,000 fisher families from the 26 villages bordering the lagoon and around 5,000 people engage in fishing there providing protein rich food source additionally for fishermen livelihood. Santharooban, et. al., (2012) recorded that Valachchenai lagoon has higher levels of Nitrogen and Phosphorous which were discharged from the fisheries harbour, paper mill, rice mills, and shrimp farms. Udagedara, et. al., (2017) also mentioned Valachchenai lagoon has been polluted by anthropogenic activities; this may lead to the degradation of aquatic resources in the lagoon. Over-fishing and environmental impacts associated with irresponsible fisheries and related activities that are related to post-tsunami recovery Post-war developments such as the Valaichchenai fishery harbour and shrimp farms have severely been degraded from the Valaichchenai lagoon (Santharooban, et. al., 2012). No previous detailed studies have been carried out on the fishery in the lagoon due to the civil unrest in the area, and no or less separate data was available on socio economics of lagoon fisher community. This study mainly focuses on the current socio-economic status of the Valaichchenai lagoon fishing community; seek proper implementations of fishery regulations including environmental impacts associated with fishery related activities. Current study paves path for proper fishery management for the relevant authorities in regulating the fishing activities, strengthening the socioeconomic status of the fishermen while maintaining the lagoon fishery \& aquatic resources in a sustainable manner.

\section{METHODOLOGY}

The stratified sampling technique with 50\% sample size was used as a probability sampling method to select the sample, representing all sub samples, since the fishermen involved in fishery activities in Valaichchenai lagoon were divided into 05 subgroups (strata) based on their landing sites. Primary data were collected by using quantitative 
method and qualitative method. Quantitative data were collected by using a close-ended method questionnaire through a field survey, which included stratified questions with five-point Likert type questions. Qualitative data such as implementations and failures of sustainability and impacts of fisheries and its related activities on the lagoon environment were collected by using interviews or informal discussions with fishermen. Identification of species was confirmed using the FAO Species Identification Guide for fishery purposes (Bruin, et. al., 1994), Fish Base World Wide Web Database (Froese and Pauly, 2019) and the internet. Catch per unit effort (CPUE) data for the main two types of fishing gear, such as gill net and cast net, were collected over twenty-one days at an equal interval during the study period and total catch and the amount of unit effort used to harvest the catch data were collected from each specific individual who is using specific or same net for unit effort (fishing day). Secondary data such as fishing population, and the number of fishing crafts operated at the landing sites and basic information about the lagoon were collected mainly from the Department of Fisheries and Aquatic Resources Development. The Statistical Package for Social Sciences (SPSS 26.0 version) and Microsoft Excel 2016 software were used to simplify the analysis work of this study. Supply chain analysis was also performed.

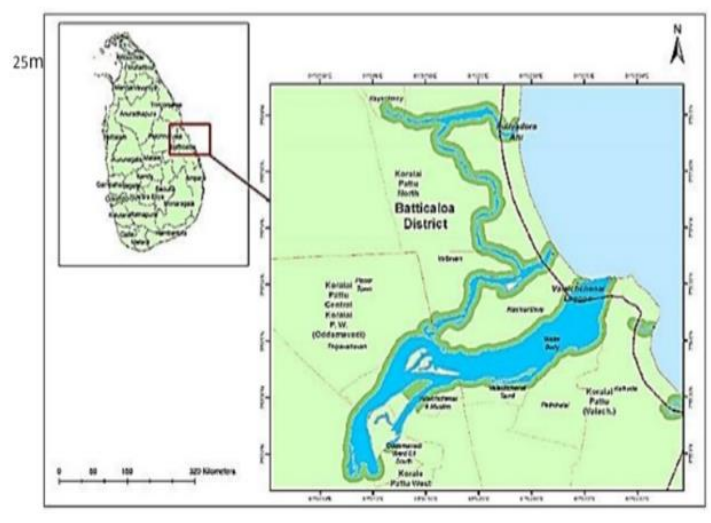

Figure 1. Location of the study area (Source: Udagedara, et. al., (2017).

\section{RESULTS AND DISCUSSION}

\section{Socio-economic status of fishermen}

According to the study, the fishers of Valaichchenai lagoon were $100 \%$ males. However, women were involved in the activities of oyster, clam and prawn catching and drying fish catch. Through an efficient study, it was found that $18.6 \%$ of respondents occupied full-time fishing and rest,
$81.4 \%$ of respondents perform part-time fishing, revealing that the majority were part-time fishermen. Nearly $44.63 \%$ of respondents caught 1$5 \mathrm{~kg}$ of fish per day, $37.60 \%$ of respondents' catch was $6-10 \mathrm{~kg}$ of fish per day while $10.33 \%$ of fishermen caught $11-15 \mathrm{~kg}$ of fish per day, where $2.07 \%$ of respondents caught $16-20 \mathrm{~kg}$ of fish per day, with $5.37 \%$ of fishermen caught more than 20 $\mathrm{kg}$ of fish per day. This indicate that the catch of majority of fishermen were $1-5 \mathrm{~kg}$ of catch per day at the landing sites of Valaichchenai lagoon. Fish catch depends on a range of factors, such as skill, fishing gear, weather, seasonal changes in biophysical parameters and, unavoidably, also an unknown portion of luck (Funfgeld, 2006).

According to the survey, $13.64 \%$ of respondents had a monthly income of less than Rs. 10,000.00, $35.12 \%$, monthly income was between Rs. $10,000.00$ and Rs. $15,000.00$, where $39.67 \%$ had a monthly income of Rs. 15,000.00 and Rs. $20,000.00$ while $11.57 \%$ income was above Rs. $20,000.00$, revealing more than half of all fishermen income was below Rs. 20,000.00 through fishing. The profit margins in lagoon fishing were generally low (Funfgeld, 2006), and Ugagedara, et. al., (2017) estimated that the average monthly income for fishers in Valaichchenai lagoon was Rs. 17,000, which matched the current study. The yearly average annual income of a household is a dominant socioeconomic indicator that greatly affects the livelihoods of fishermen (Hossain, et. al., 2009). Current study found that $32.23 \%$ of respondents belonged to the category of annual income below Rs. $100,000.00$, while $47.52 \%$ of respondents' annual income range was between Rs. 100,000.00 to Rs. $200,000.00$, with $10.33 \%$ of respondents with an annual income in between Rs. 200,000.00 to Rs. $300,000.00$ category, $9.92 \%$ of respondents' annual income level was above Rs. 300,000.00 (Figure 2).

Out of 242 respondents, $18.18 \%$ represent fishermen who are in the age group 20-30 years, while $28.5 \%$ were in between $31-40$ years, where $17.36 \%$ and $35.95 \%$ represent fishermen who were aged between $41-50$ and above 50 years, respectively. $4.96 \%$ of fishermen have not received any education and fishermen who are at primary level represent $52.07 \%$ of the sample. $34.71 \%$ of fishermen have received the secondary level of education, $8.26 \%$ have reached ordinary level of education, and there were no undergraduate fishermen in that community. Nearly $31.40 \%$ of respondents have 1-5 years of fishing experience, while $17.36 \%$ have 6-10 years of experience, and 
$22.31 \%$ have $11-15$ years of experience. Nearly $28.93 \%$ of respondents had above 15 years of fishing experience.

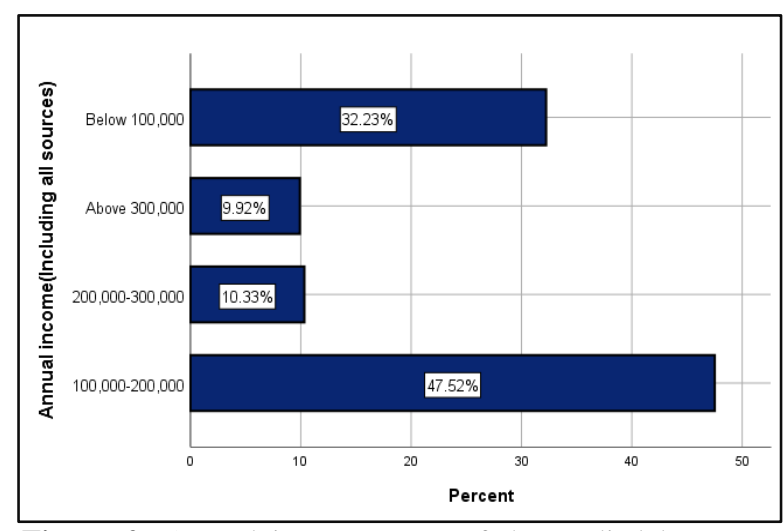

Figure 2: Annual income range of the studied lagoon fishermen (SPSS output from field information)

\section{Fishing gears and crafts operated in the study area.}

The types of fishing gears mostly used for fishing activities in the landing sites of Valaichchenai lagoon are shown in Figure 3.

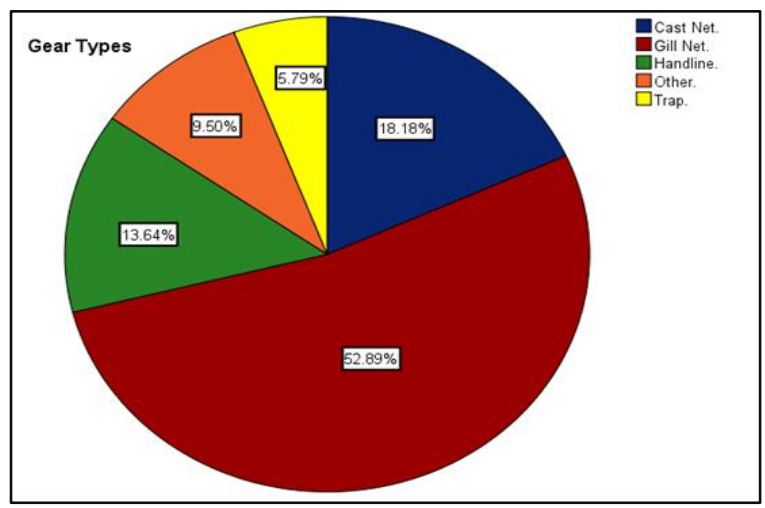

Figure 3: Percentage composition of fishing gears mostly used for fishing in the study area (SPSS output from field information)

Majority of respondents used gill nets (52.89\%), $18.18 \%$ of fishermen used cast nets while $13.64 \%$ used hand lines and $5.79 \%$ of respondents used traps for fishing. $9.50 \%$ of respondents used other gear types such as scoop net/athangu and longlines showing that majority of fishermen use gill nets for fishing in Valaichchenai lagoon. Gill net (mostly set in the evenings), cast net, and traps are used on a daily basis, which were used in the morning from 6.00 am to $11.00 \mathrm{am}$ and in the evenings from 5.30 $\mathrm{pm}$ to $6.00 \mathrm{am}$. Other gears, such as scoop net, longline, and hand line, were used any time of the day. Fishermen attached baits (chicken intestine, cattle fish pieces and commercially available trash fish) on gears such as hand line, long line and traps to attract the target species. In recent times, to attract the target species fishermen have used artificial lights such as torches, kerosene lamps, and petromax lamps.

In the field survey, it was found that artisanal fisheries have been identified as common activity in the lagoon. Fishermen used trammel net too, which was prohibited in the lagoon area. Moreover, brush pile, harpoons, karappu (using artificial lights such as torch light to attract the fishes and catch them by using long wooden basket) and parikudu/kuddupedi (small L shaped wooden box) were, only used by a limited number of fishermen due to high availability of modern fishing gears with high efficiency.

Analysis of different kinds of fishing crafts used by fishermen shows that a considerable majority of respondents used an outrigger lagoon canoe (Thoni). It is used for cast net fishing, gill net fishing, trap fishing, handline fishing and longline fishing. A substantial number of fishers in Valaichchenai lagoon also used fishing gears, such as scoop net, which do not require a fishing craft. Motorized crafts are prohibited in the lagoon because of sound pollution and oil spilling.

\section{Species composition}

According to the interviews and direct field observations, Green chromide and Common carp were the species mostly caught in the Valaichchenai lagoon, and Mullet, Double spine foot, and Seabass were the high-priced species. Three prawn types, namely Green Tiger prawn, Indian White shrimp and Wild King Tiger prawn, were caught in the Valaichchenai lagoon. Prawns were mainly caught using traps (fyke net) and prawn nets, cast net, and also scoop net. Mud crabs were caught mainly by crab traps and crab nets. Prawns and crabs have high market demand, and they are exported to other countries. Clams and oysters are collected by hand or using knives and they are sold in the local markets.

\section{Marketing system}

The marketing system of the Valaichchenai lagoon area is shown in Figure 4. It was found that $11.57 \%$ of the fishermen sold their captured species to consumers directly, $54.55 \%$, to fish vendors and $33.88 \%$ sold their species to wholesalers.

Lagoon fishermen do not receive higher prices in selling their harvest at the lagoon site because of mobile traders who buy the fish directly at the landing sites, packed fishes in iced boxes and 
transport to the nearest market using bicycles and motorcycles.

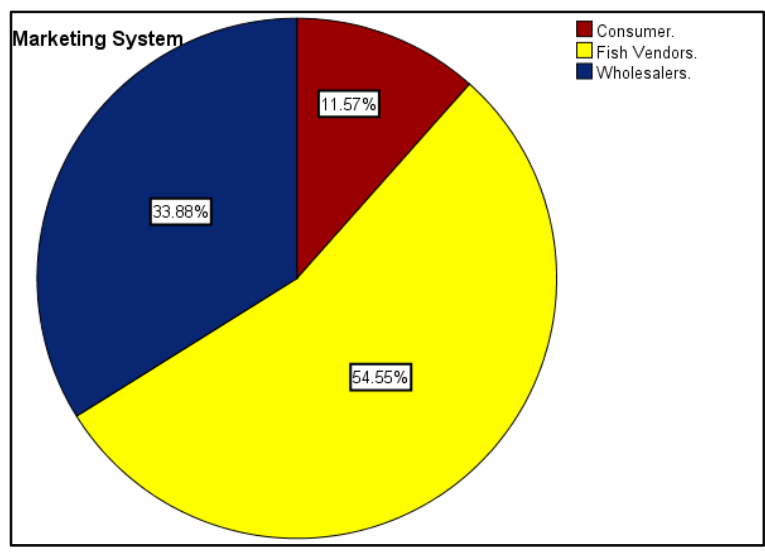

Figure 4: Percentage composition of marketing system in the study area (SPSS output from field information)

\section{Supply chain}

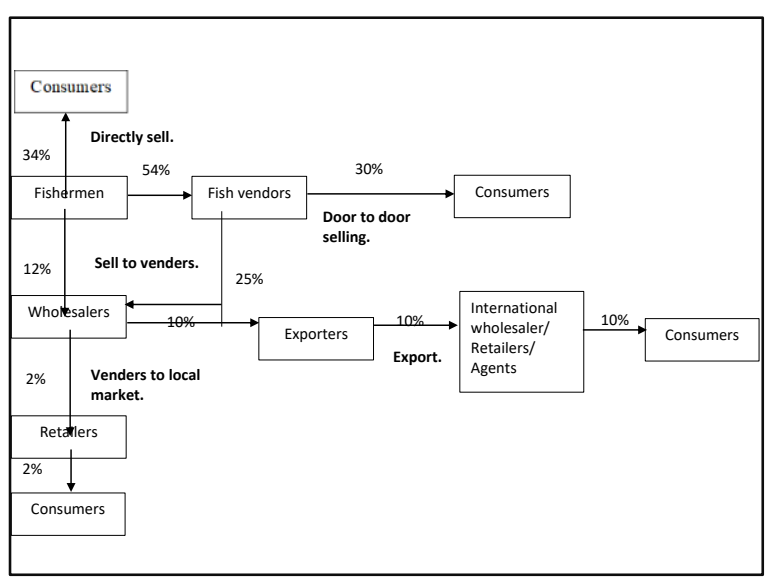

Figure 5: Supply chain system of Valaichchenai lagoon fishery (SPSS output from field information)

The status of the marketing channel of the species with high demand of Valaichchenai lagoon fishery is shown in Figure 5. Prawn and crab were high demanded and export-oriented products. Islam, et. al., (2014) reported in detail on marketing channels were product flow from producers to ultimate consumers.

\section{Catch per unit effort analysis}

According to the data collected from each specific individual who used a gill net and a cast net, the catch per unit effort (kg per net square meter-day) of the fisherman, catch per unit effort of gill net was in between 0.009 to $0.027 \mathrm{~kg}$ during the study period. Catch per unit effort ( $\mathrm{kg}$ per day) of the fisherman for the cast net used was in between 0.75 to $3.1 \mathrm{~kg}$. The catch per unit effort (CPUE) in fisheries and conservation biology is an indirect measure of the abundance of a target species (Hossain, et. al., 2009; Rosario, 2017).

The overall mean value of awareness of the sustainable fisheries is 3.74 , hence Valaichchenai lagoon fishermen have good awareness of the importance of fishery sustainability, and they have moderate awareness on importance of lagoon environmental protection and suggestions to maintain the sustainable fishery and reduce negative environmental impacts, the overall mean value for those are 3.33 and 3.35 respectively. But in nature, they give more priority to their income than sustainable fishery and lagoon environmental protection. $51.2 \%$ of fishermen reported poor storage facilities as a major constraint in the Valaichchenai lagoon landing sites. Then, $22.3 \%$ of fishermen mentioned poor transportation network, $16.9 \%$ of respondents indicated lack of hygiene and sanitation and $7.4 \%$ of respondents said delay in selling as constraints. $2.1 \%$ of respondents mentioned conflicts among fishermen were minor in the Valaichchenai lagoon landing sites. 34.3\% of fishermen reported the low economic value of lagoon fishes as a major constraint in the Valaichchenai lagoon marketing sector. Then $31.0 \%$ of respondents said fluctuation in price, $28.5 \%$ of fishermen mentioned about lack of market infrastructure and $3.7 \%$ of respondents indicated the delay in payment and $2.5 \%$ of respondents said competition among traders as constraints.

\section{Implementations and failures of sustainable fishery in Valaichchenai lagoon area}

Inland Fisheries Management Regulations No.2 of 1996 such as licensing system, prohibition of mesh size $85 \mathrm{~mm}$ or below, surrounding or towing nets (such as purse seine, trawl net), trammel net, monofilament netting material, cancellation of license for penalties or imprisonment according to the level of violation of rule and regulations were currently implemented in the lagoon. Seabass culture system to increase income of fishing community while reducing the issues rising from over-exploitation due to intense lagoon fishing were also implemented in the lagoon. Overexploitation of the fishery at the very least means lower returns from the fishery and, at worst, can lead to the elimination of biological species (Wijayaratne, 2001). The lagoon has open access for fishing; fishermen have free access to the lagoon even without fishing licence. Therefore, proper monitoring system should be implemented and the effects of oversupply of fishing crafts thereby increment of fishermen beyond actual 
demand (Gunawardena and Wickramasinghe, 2009).

No species or size limitations were obeyed by the lagoon fishermen in the lagoon fishery and no offseason or time limitations (especially during the breeding and spawning seasons) were implemented. One fisheries inspector (FI) was in charge of the five landing sites, so it was practically impossible to monitor the whole lagoon. Therefore, fishermen tend to catch undersized fish (juveniles) species during the fishing seasons (prawns and crabs), by-catch of live juveniles were high and fishermen do not release these back into the lagoon. Moreover, some fishing gears which were frequently used in the lagoon, such as scoop net, traps (Fyke net) were considered problematic because these catch all sizes of fishes including pre-matured species. Karakulak, et. al., (2012) reported that the high price and profitability situations may encourage over-fishing, resulting in stock depletion and final extinction of species, and the catch of non-target species or bycatch, immature individuals, and economically nonimportant species may affect the fishery sustainability and reduce fish catch in the future. Further, seabass species cultured in cages at Valaichchenai lagoon do not reach marketing size when they were harvested due to anthropogenic activities.

\section{Environmental impacts of fisheries and related activities in Valaichchenai lagoon area}

Traps (including fyke nets) and scoop nets used to catch prawns and crabs, as well as hand or knives used to collect mussels and oysters, seagoing boat movements to reach the harbour and anchorages, and the use of outboard motors and propellers in shallow seagrass beds affect the seagrass and benthic environment of the lagoon. Oil spills through boats and effluent discharges of aquaculture farms are also harmful. Fish offal and waste discharge from the Valaichchenai fisheries harbour may also affect the lagoon environment and the degradation of excess feeds (commercially available trash fish) were harmful to the particular lagoon. Sand mining to increase the lagoon depth in facilitating the movement of seagoing boats may destroy the seagrass bed by increasing turbidity. This can change the currents, wave action, tidal fluctuations and the transport of sediments along the coast. Moreover, feed waste and faecal matter disposal from the aqua cage cultures pollute the lagoon environment.
Fiberglass waste from boat repairing centres in the fisheries harbour may contaminate with the water and can be inhaled by the species, settle in the airway and lungs and end up in the food chain (Mithipala, 2013). Sound pollution is a minor issue in the Valaichchenai lagoon, and this may not kill the fish directly, but can disrupt their ability to find food, mates, or avoid of predators.

Other than fisheries and related activities, there are other environmental issues that have been observed on the landing sides, such as salinity changes due to Maduru Oya mixing, agriculture runoff, mangrove exploitation, invasive alien species, and illegal construction and land filling. The effects of lack of enforcement mechanism of management rules and regulations and failures in monitoring can lead to the depletion of lagoon fishery resources were stressed in FAO, 2012. Moreover, Miththapala, (2013) indicated the importance of lagoon environment but due to overexploitation, illegal fishing, coastal infrastructure, aquaculture development and pollution, habitat destruction, eutrophication, changes in sedimentation and waterflow may occur.

\section{CONCLUSIONS}

During the survey, it was found that a total of 12 types of fishing gear, and the outrigger lagoon canoe (Thoni) are used in the Valaichchenai lagoon. A total number of 38 species were identified at the landing site. In marketing, fish vendors play a major role, and a small number of fishermen directly market their catches. Supply chain includes both local and foreign market interventions. On average, fishermen caught 0.016 $\mathrm{kg} /$ net square meter-day and $2.140 \mathrm{~kg} /$ day using a gill net and cast net respectively. For sustainable fishery, regulation for mesh sizes and certain unauthorized activities, a licensing system, penalties or imprisonment according to the level of violations, and seabass cage culture are taking place in the Valaichchenai lagoon, but the implementations are inadequate to manage the lagoon in a sustainable manner. The environmental impacts associated with irresponsible fisheries, shrimp farm/aquaculture and Valaichchenai fishery harbor are deteriorate the water quality, visual pollution, oil spiling, sound pollution, etc. Solutions and recommendations for improving sustainable fishery and lagoon environmental protection, such as introducing co-management system, implementing voluntary code of conducts, strengthening rules and regulations implementation, conducting awareness and training 
programmes and etc, will help the further management and development.

\section{REFERENCES}

Bruin, G., Russell, B. and Bogusch, A. 1994. The Marine Fishery Resources of Sri Lanka. Rome: Food and Agriculture Organization of the United Nations.

Froese, R. and Pauly, D. 2019. FishBase. World Wide Web electronic publication. [Online] Available at: https://www.fishbase.de/ [Accessed 2112 2019].

Funfgeld, H. 2006. Fishing in muddy waters.

Gunawardena, A. and Wickramasinghe, K., 2009. Social and economic impacts of resettlement on Tsunami affected coastal fishery households in Sri Lanka. Forced to Move: Involuntary Displacement and Resettlement-Policy and Practice, pp.83-108.

Hossain, M.I., Siwar, C., Mokhtar, M.B., Dey, M.M. and Jaafar, A.H. 2009. Socio-economic Condition of Fishermen in Seasonal Floodplain Beels in Rajshahi District, Bangladesh. Research Journal Hellin, J. and Meijer, M. 2006. Guidelines for value chain analysis. s.1.:s.n. of Social Sciences, Volume 4, pp. 7481.Miththapala, S., 2013. Lagoons and estuaries (Vol. 4). IUCN.

Islam, M., Haque, M., Rabbani, M. and Sharmin, S. 2014. Marketing of shrimp in Bangladesh - A value chain analysis. Bangladesh Agricultural University, 12(2), pp. 359-368.

Karakulak, F.S. and Erk, H., 2008. Gill net and trammel net selectivity in the northern Aegean Sea, Turkey. Scientia Marina, 72(3), pp.527540.

Miththapala, S. 2013. Lagoons and estuaries (Vol. 4). IUCN.

Rosario, G. 2017. Catch Per Unit Effort SlideShare. [Online] Available at: https://www.slideshare.net/GeromeRosario/cpu e [Accessed 2501 2020].

Santharooban, S., Vinobaba, P. and Fernando, R. 2012. Water pollution in Valaichchanai lagoon due to different industrial effluents (RP0628).

Udagedara, S., Fernando, D., Perera, N., Tanna, A. and Bown, R. 2017. A first record of Halodule pinifolia Miki den Hartog, and new locality of nationally endangered Halophila beccarii Asch, from the eastern coast of Sri Lanka. International Journal of Aquatic Biology, 5(5), pp.328-335.

Wijayaratne, B. 2001. Coastal fisheries in Sri Lanka: some recommendations for future management. The United Nations University. 